\title{
Pengaruh Pembelajaran Blended Learning terhadap Nilai-Nilai Karakter Siswa SD Negeri 26 Teluk Bayur
}

\author{
Illiyinna Rahmi ${ }^{1}$, Rahmi Wiza ${ }^{2}$ \\ Illiyinnarahmi99@gmail.com ${ }^{1}$, rahmiwiza@fis.unp.ac.id ${ }^{2}$ \\ Universitas Negeri Padang ${ }^{1,2}$
}

\begin{tabular}{l}
\hline ARTICLE INFO \\
\hline Article history: \\
Received 5 Agustus 2021 \\
Revised 24 Agustus 2021 \\
Accepted 31 Agustus \\
2021 \\
\hline
\end{tabular}

Keywords:

Blended learning, nilainilai karakter, Siswa SD

\section{Clonflict of Interest:}

None

\section{Funding:}

None

\begin{abstract}
Penelitian ini bertujuan untuk mengetahui pengaruh pembelajaran blanded learning terhadap nilai-nilai karakter siswa. Penelitian ini menggunakan metode kuantitatif dengan jenis korelasional. Penelitian ini dilaksankan di SD Negeri 26 Teluk Bayur yang beralamatkan dijalan Rawang Timur IX Sutan Syahrir kota Padang. Populasi dalam penelitian ini adalah seluruh siswa SD Negeri 26 Teluk Bayur. Penelitian ini dilaksanakan pada tanggal 9 Juni 2021. Penelitian ini digunakan untuk mengetahui seberapa besar pengaruh antara variabel bebas (independent variable) terhadap variabel terikat (dependent variable). Sampel penelitian berjumlah 28 siswa kelas $\mathrm{V}$ dengan teknik pengumpulan data yaitu menyebarkan angket kepada responden. Hasil penelitian ini dapat disimpulkan bahwa tidak terdapat pengaruh yang signifikan antara pembelajaran blanded learning terhadap nilai-nilai karakter siswa.
\end{abstract}

Corresponding Author: Illiyinna Rahmi, Department Islamic Education, Faculty of Social Science Universitas Negeri Padang, Indonesia, Email: Illiyinnarahmi99@gmail.com Phone: +62812-7733-3469

(C) () Copyright $\odot 2021$, Author(s)

\section{Pendahuluan}

Blended learning merupakan gabungan pembelajaran lansung dan pembelajaran daring/online, peserta didik harus mencari gaya belajar yang aktif sesuai engan dirinya, pembelajaran ini memperkuat pembelajaran teknologi masa kini. (Hussin et al., 2017).

Proses pembelajaran blanded learning tentu membawa perubahan karakter siswa, karena proses pembelajaran ini menuntut siswa agar lebiih aktif mencari gaya pembelajaran sendiri sehingga banyaknya siswa yang merasa jenuh, bosan, dan merasa tidak semangat untuk belajar. 
Satuan pendidikan sekolah dasar saat ini menggunakan sistem pembelajaran tematik, dimana pada sistem ini semua mata pelajaran terangkup dalam satu tema pembelajaran, dan setiap tema itu terdiri dari beberapa sub tema yang mempunyai tujuan pemebelajaran berdasarkan pengetahuan, sikap dan keterampilan. Dari penilaian sikap pembelajaran terdiri dari sikap religius, jujur, teliti \& disiplin, mandiri, dan sopan santun.

Berdasarkan hasil wawancara yang peneliti dapatkan pada masa praktek lapangan ketika itu dan setelah wawancara pada tanggal 25 Maret 2021 bahwa penerapan pembelajaran blended learning siswa dibagi 3 kali dalam seminggu belajar secara daring dan 3 kali belajara secara luring, namun banyak permasalahan karakter pada saat pembelajaran daring berlansung diantaranya masih banyak siswa yang kurang semangat belajar dalam melakukan proses pembelajaran dikarenakan jadwal pembelajaran yang tidak menentu, tidak disiplinnya siswa dalam mengumpulkan tugas dan kurangnya kejujuran siswa dalam menyelesaikan tugas-tugas yang diberikan oleh gurunya. Sementara itu pada saat pembelajaran luring atau tatap muka siswa dapat dikondisikan atau dikontrol oleh gurunya, sehingga siswa dapat memperbaiki karakter yang dimilikinya secara bertahap.

Perbedaan penelitian ini dengan penelitian sebelumnya yaitu pada penelitian Rizki Firmansyah yang berjudul "Pengaruh Blended Learning terhadap hasil belajar PAI siswa kelas X SMAN 8 Bandar Lampung” memiliki kaitan dengan penelitian ini yaitu kaitan persamaannya terletak pada variabel $(X)$ pembelajaran blanded learning dan memiliki perbedaan variabel pada variabel (Y) nilai-nilai karakter.

\section{Tinjauan Pustaka}

\section{A. Pembelajaran Blanded Lerning \\ 1) Pengertian blended learning}

Blended Learning adalah pembelajaran dengan melibatkan pembelajaran secara lansung (syncronous) dengan pembelajaran tidak langsung (a syncronou). Blended learning sebagai kombinasi karakteristik pembelajaran tradisional dan lingkungan pembelajaran elektronik. (Salma et al., 2013)

Blended learning merupakan gabungan pembelajaran langsung dan pembelajaran daring/online, siswa harus mencari gaya belajar yang aktif sesuai dengan dirinya, pembelajaran ini memperkuat pembelajaran di dalam kelas dengan memanfaatkan teknologi masa kini. (Hussin et al., 2017)

\section{2) Tujuan Pembelajaran Blanded}

Pembelajaran blanded learning tentu memiliki tujuan dan pencapaian sesuai dengan yang diharapkan, adapun tujuan pembelajaran blanded learning menurut (Husamah, 2014) diantaranya: (1) Membantu siswa agar dapat berkembang, (2) Menyediakan peluang praktis serta realistis bagi siswa , serta (3) Jadwal yang fleksibelitas bagi siswa.

\section{3) Karakteristik Pembelajaran Blanded Learning}

Pembelajaran blanded learning juga memiliki karakteristik tersendri menurut (Soekartawi \& Librero, 2002), diantranya: (1) Penggabungan 
Illiyinna Rahmi dan Rahmi Wiza: Pengaruh Pembelajaran Blended Learning terhadap ...

segala proses dalam pembelajaran, (2) Sebagai sebuah kombinasi antara belajar via online dengan tatp muka, (3) Sebagai campuran yang efektif bagi pendidik atau guru dalam proses pembelajaran, (4) Memiliki peran yang sama antara guru dan siswa.

\section{4) Kelebihan dan Kekurangan Pembelajaran Blanded Learning}

Kelebihan pembelajaran blanded learning menurut (Susandi, 2017) di antaranya: (1) siswa dapat secara mempelajari materi pelajaran dengan mandiri, (2) siswa bisa berdiskusi dengan guru diluar jam tatap muka, (3) guru dapat memperkaya materi melalui fasilitas internet, (4) guru bisa meminta siswa membaca materi dengan mantap, (5) siswa bisa saling berbagi materi ataupun dalam bentuk file kepada teman lainnya.

Berdasarkan kelebihan pembelajaran blanded laearning, tentu ada kekurangannya menurut (Susandi, 2017) diantranya: (1) media yang digunakan sangat beragam, oleh karena itu sulit diterapkan jika sarana dan prasarana tidak memadai, (3) kurangnya pengetahuan serta penggunaan teknologi bagi siwa, guru, maupun orang tua.

\section{B. Nilai- Nilai Karakter \\ 1) Pengertian nilai karakter}

Nilai karakter yang dimaksud dalam penelitian ini adalah nilai yang tertanam dari pendidikan karakter, pendidikan karakter merupakan suatu sistem penenaman nilai-nilai karakter kepada warga sekolah yang meliputi komponen pengetahuan, kesadaran atau kemauan dan tindakan untuk melaksanakn nilai-nilai tersebut, baik terhadap Tuhan Yang Maha Esa, diri sendiri, sesama, dan lingkungan.(SP, 2016).

Menurut (Sudrajat, 2011) ada 18 nilai pendidikan karakter yaitu "religius, jujur, toleransi, disiplin, kerja keras, kreatif, mandiri, demokratis, ingin tahu, semangat kebangsaan, cinta tanah air, menghargai prestasi, bersahabat, cinta damai, gemar membaca, peduli lingkungan, peduli sosial, tanggung jawab".

\section{Metodologi}

Penelitian ini menggunakan pendekatan kuantitatif dengan jenis korelasional. Populasi penelitian ini adalah siswa SD Negeri 26 Teluk Bayur yang berjumlah 162. Peneliti mengambil satu kelas V sebagai anggota sampel yaitu berjumlah 28. Data dikumpulkan dengan angket menggunakan skala likert. Data dianalisis dengan menggunakan rumus uji parsial (uji T) dan uji simultan (uji F).

\section{Hasil dan Pembahasan}

\section{A. Hasil}

\section{Proses pembelajaran daring}

Pada proses ini siswa diminta untuk melakukan kegiatan setiap paginya yang berhubungan dengan spritual yang dikrimkan setiap pertemuannya di 
whatsapp group kelas seperti absensi shalat dhuha dan kegiatan menolong orang tua.

Kegiatan inti, dimana guru membagikan materi pembelajaran melalui whatsapp group dimana materi pembelajarannya berbentuk vidio ataupun penjelasan dari guru berdasarkan buku tema atau buku pembelajaran kelas V, setelah itu guru memberikan waktu kepada siswa untuk bertanya apakah sudah memahami instruksi ataupun materi yang telah dibagikan guru kepada siswanya melalui whatsapp group tersebut.

Terakhir yaitu penutup, pada proses ini guru memberikan evaluasi terhadap materi pembelajaran yang telah disampaikan melalui whatsapp group kepada siswanya, selanjutnya siswa diberikan tugas untuk materi pada hari tersebut dan diberitahukan batas waktu pengumpulan tugasnya.

\section{Proses Pembelajaran Tatap Muka}

Pada proses pembelajaran tatap muka, berdasarkan hasil wawancara menjelaskan bahwa proses pembelajaran tatap muka tetap berdasarakan RPP satu lembar yaitu : Pada proses ini siswa diminta melakukan kegiatan awal sebelum pembelajaran dimulai seperti: (1) kelas dibuka dengan salam, menanyakan kabar, dan mengecek kehadiran siswa (2) kelas dilanjutkan dengan doa dipimpin oleh salah seorang siswa (3) Siswa difasilitasi untuk bertanya jawab pentingnya mengawali setiap kegiatan dengan doa. Selain berdoa, guru dapat memberikan penguatan tentang sikap syukur (4) Siswa diajak menyanyikan Lagu Indonesia Raya. Guru memberikan penguatan tentang pentingnya menanamkan semangat kebangsaan (5) Siswa diminta memeriksa kerapian diri dan kebersihan kelas (6) Siswa memperhatikan penjelasan guru tentang tujuan, manfaat, dan aktivitas pembelajaran yang akan dilakukan (7) Siswa menyimak penjelasan guru tentang pentingnya sikap disiplin yang akan dikembangkan dalam pembelajaran (8) Pembiasaan membaca. Siswa dan guru mendiskusikan perkembangan kegiatan literasi yang telah dilakukan (9) Siswa diajak menyanyikan lagu daerah setempat untuk menyegarkan suasana kembali.

Kegiatan Inti, yaitu proses ini siswa diminta melakukan setiap proses pembelajaran sesuai materi yang diajarkan siswa pada hari tersebut dengan cara (1) mengamati gambar pada buku pelajaran siswa dan didampingi oleh guru kelas (2) siswa diminta tanya jawab oleh guru mengenai materi pembelajaran siswa (3) siswa melakukan diskusi ataupun evaluasi seperti latihan atau tugas yang diberikan guru.

Pada proses penutup siswa bersama guru melakukan refleksi atas pembelajaran yang telah berlangsung, siswa bersama guru menyimpulkan hasil pembelajaran pada hari itu, dan kegiatan akhir siswa diminta untuk doa bersama dipimpin oleh salah seorang siswa

\section{Uji Coba Instrument Penelitian}

\section{a. Uji Validitas}

Dalam uji validitas peneliti menggunakan aplikasi IBM SPSS Statistic Version 20 For Windows. Berikut hasil uji validitas variabel 
Illiyinna Rahmi dan Rahmi Wiza: Pengaruh Pembelajaran Blended Learning terhadap ...

pembelajaran blanded learning (X) dan nilai-nilai karakter siswa (Y) dengan menggunakan 28 responden.

\section{1) Pembelajaran Blended Learning (X)}

Tabel 1. Uji Validitas Pembelajaran Blended Learning

\begin{tabular}{|cccc|}
\hline No item & R hitung & R tabel & keterangan \\
\hline 1. & 0,534 & 0,532 & Valid \\
\hline 2. & 0,674 & 0,532 & Valid \\
\hline 3. & 0,621 & 0,532 & Valid \\
\hline 4. & 0,675 & 0,532 & Valid \\
\hline 5. & 0,621 & 0,532 & Valid \\
\hline 6. & 0,376 & 0,532 & Tidak Valid \\
\hline 7. & 0,273 & 0,532 & Tidak Valid \\
\hline 8. & 0,409 & 0,532 & Tidak Valid \\
\hline 9. & 0,675 & 0,532 & Valid \\
\hline 10. & 0,692 & 0,532 & Valid \\
\hline 11. & 0,534 & 0,532 & Valid \\
\hline 12. & 0,745 & 0,532 & Valid \\
\hline 13. & 0,517 & 0,532 & Tidak Valid \\
\hline 14. & 0,812 & 0,532 & Valid \\
\hline 15. & 0,394 & 0,532 & Tidak Valid \\
\hline
\end{tabular}

lebih kecil dari $\mathrm{r}_{\text {tabel }}$ maka item instrumennya tidak valid atau tidak layak untuk digunakan.

Hasil dari uji validitas pembelajaran blended learning (variabel $\mathrm{X}$ ) tersebut diketahui bahwa terdapat 5 buah item instrumen yang tidak valid yaitu pada nomor 6,7,8,13, dan 15 item yang tidak valid tidak digunakan dalam penelitian. Kesimpulannya item yang valid terdapat 10 item yang penomorannya di urutkan kembali untuk pengambilan data penelitian.

\section{2) Nilai-nilai Karakter (Y)}

Tabel 2. Uji Validitas Nilai-nilai Karakter

\begin{tabular}{|c|c|c|c|}
\hline No item & R hitung & R tabel & keterangan \\
\hline $\mathbf{1 .}$ & 0,569 & 0,532 & Valid \\
\hline $\mathbf{2 .}$ & 0,501 & 0,532 & Tidak Valid \\
\hline $\mathbf{3 .}$ & 0,330 & 0,532 & Tidak Valid \\
\hline $\mathbf{4 .}$ & 0,626 & 0,532 & Valid \\
\hline $\mathbf{5 .}$ & 0,410 & 0,532 & Tidak Valid \\
\hline $\mathbf{6 .}$ & 0,567 & 0,532 & Valid \\
\hline $\mathbf{7 .}$ & 0,102 & 0,532 & Tidak Valid \\
\hline
\end{tabular}




\begin{tabular}{|c|c|c|c|}
\hline $\mathbf{8 .}$ & 0,535 & 0,532 & Valid \\
\hline $\mathbf{9 .}$ & 0,854 & 0,532 & Valid \\
\hline $\mathbf{1 0 .}$ & 0,626 & 0,532 & Valid \\
\hline $\mathbf{1 1 .}$ & 0,797 & 0,532 & Valid \\
\hline $\mathbf{1 2 .}$ & 0,489 & 0,532 & Tidak Valid \\
\hline $\mathbf{1 3 .}$ & 0,615 & 0,532 & Valid \\
\hline $\mathbf{1 4 .}$ & 0,762 & 0,532 & Valid \\
\hline $\mathbf{1 5 .}$ & 0,496 & 0,532 & Tidak Valid \\
\hline $\mathbf{1 6 .}$ & 0,626 & 0,532 & Valid \\
\hline $\mathbf{1 7 .}$ & 0,660 & 0,532 & Valid \\
\hline $\mathbf{1 8 .}$ & 0,580 & 0,532 & Valid \\
\hline $\mathbf{1 9 .}$ & 0,034 & 0,532 & Tidak valid \\
\hline $\mathbf{2 0 .}$ & 0,159 & 0,532 & Tidak valid \\
\hline $\mathbf{2 1 .}$ & 0,694 & 0,532 & Valid \\
\hline $\mathbf{2 2 .}$ & 0,250 & 0,532 & Tidak valid \\
\hline $\mathbf{2 3 .}$ & 0,819 & 0,532 & Valid \\
\hline $\mathbf{2 4 .}$ & 0,660 & 0,532 & Valid \\
\hline $\mathbf{2 5 .}$ & 0,535 & 0,532 & valid \\
\hline
\end{tabular}

Dari tabel diatas dengan jumlah

responden $\mathrm{N}=14$ maka sesuai taraf signifikan 5\% maka dikatakan valid apabila hasil yamg diperoleh minimal 0,532. Kesimpulannya jika

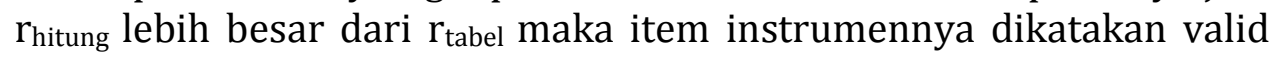
atau dapat digunakan, sebaliknya apabila $r_{\text {hitung }}$ lebih kecil dari $r_{\text {tabel }}$ maka item instrumennya tidak valid atau tidak dapat digunakan.

Hasil dari uji validitas nilai-nilai karakter (variabel Y) tersebut diketahui bahwa terdapat 9 buah item instrumen yang tidak valid yaitu pada nomor $2,3,5,7,12,15,19,20$, dan 22 . Item yang tidak valid tidak dapat digunakan dalam penelitian. Kesimpulannya, item yang valid terdapat 16 item yang penomorannya di urutkan kembali untuk pengambilan data penelitian.

\section{b. Uji Reliabilitas}

\section{1) Pembelajaran blanded learning}

Tabel 3. Hasil Uji Reliability Pembelajaran Blanded Learning

\begin{tabular}{|r|c|}
\hline \multicolumn{2}{|c|}{ Reliability Statistics } \\
\hline $\begin{array}{c}\text { Cronbach's } \\
\text { Alpha }\end{array}$ & $\begin{array}{c}\text { N of } \\
\text { Items }\end{array}$ \\
\hline .823 & 15 \\
\hline
\end{tabular}

Berdasarkan tabel di atas hasil uji reliabilitas nilai alpha cronbach's, $r_{\text {tabel }}$ yang didapatkan senilai 0,823 dan tergolong di nilai antara 0,801,00 maka hasil uji tersebut dikatakan reliabel (sangat tinggi).

\section{2) Nilai-nilai karakter}


Illiyinna Rahmi dan Rahmi Wiza: Pengaruh Pembelajaran Blended Learning terhadap ...

Tabel 4. Hasil Uji Reliability Nilai-nilai Karakter

\begin{tabular}{|r|r|}
\hline \multicolumn{2}{|c|}{ Reliability Statistics } \\
\hline Cronbach's Alpha & $\begin{array}{c}\text { N of } \\
\text { Items }\end{array}$ \\
\hline .882 & 25 \\
\hline
\end{tabular}

Berdasarkan tabel diatas hasil uji reliabilitas nilai alpha cronbach's, $\mathrm{r}_{\text {tabel }}$ yang didapatkan senilia 0,882 dan tergolong dinilai antara 0,80-1,00. Maka hasil uji reliabilitas tersebut dikriteriakan sangat tinggi.

\section{Uji Persyaratan Analisis Data}

Uji persyaratan analisis dalam penelitian ini dengan menggunakan uji normalitas dan uji linieritas. Dalam uji normalitas dan uji linieritas peneliti menggunakan program SPSS For Windows 2020.

a. Uji Normalitas

Uji normalitas bertujuan untuk mengetahui normal atau tidaknya data penelitian. Berikut hasil perhitungan uji normalitas pengaruh pembelajaran blanded learning (X) terhadap nilai-nilai karakter (Y) menggunakan SPSS For Windows 2020.

Tabel 5. Hasil Uji Normalitas

\begin{tabular}{|c|c|c|}
\hline \multicolumn{3}{|c|}{ One-Sample Kolmogorov-Smirnov Test } \\
\hline & & $\begin{array}{c}\text { Unstandar } \\
\text { dized } \\
\text { Residual }\end{array}$ \\
\hline $\mathrm{N}$ & & 27 \\
\hline \multirow{3}{*}{$\begin{array}{l}\text { Normal } \\
\text { Parameters }{ }^{a, b}\end{array}$} & Mean & $0 \mathrm{E}-7$ \\
\hline & Std. & 4.5872079 \\
\hline & Deviation & 1 \\
\hline \multirow{3}{*}{$\begin{array}{l}\text { Most Extreme } \\
\text { Differences }\end{array}$} & Absolute & .189 \\
\hline & Positive & .189 \\
\hline & Negative & -.111 \\
\hline \multicolumn{2}{|c|}{ Kolmogorov-Smirnov Z } & .982 \\
\hline \multicolumn{2}{|c|}{ Asymp. Sig. (2-tailed) } & .290 \\
\hline \multicolumn{3}{|c|}{ a. Test distribution is Normal. } \\
\hline \multicolumn{3}{|c|}{ b. Calculated from data. } \\
\hline
\end{tabular}

Berdasarkan aplikasi SPPS Version 20 For Windows dengan dasar pengambilan keputusan probabilitas dalam uji normalitas jika nilai siginifikan $<0,05$ maka nilai residual berdistribusi tidak normal. Dan jika nilai signifikan $>0,05$ maka nilai residual berdistribusi normal. Jadi, dapat disumpulkan hasil uji normalitas di atas nilai signifikansinya 0,290 > 0,05 maka data tersebut berdistribusi normal. 


\section{b. Uji Linieritas}

Uji linieritas bertujuan untuk menunjukkan apakah variabel X dan Y mempunyai hubungan yang linier. Berikut hasil perhitungan uji linieritas pembelajaran blanded learning (X) terhadap nilai-nilai karakter (Y) menggunakan SPSS For Windows 2020.

Tabel 6. Hasil Uji Linieritas

\begin{tabular}{|c|c|c|c|c|c|c|c|}
\hline \multicolumn{8}{|c|}{ ANOVA Table } \\
\hline & & & $\begin{array}{l}\text { Sum of } \\
\text { Squares }\end{array}$ & df & $\begin{array}{c}\text { Mean } \\
\text { Squa } \\
\text { re }\end{array}$ & $\mathbf{F}$ & $\begin{array}{c}\text { Sig } \\
\text { · }\end{array}$ \\
\hline \multirow{5}{*}{$\begin{array}{l}\text { Nilai- } \\
\text { nilai } \\
\text { karakte } \\
\mathbf{r} * \\
\text { pembel } \\
\text { ajaran } \\
\text { blanded } \\
\text { learnin } \\
\text { g }\end{array}$} & \multirow{3}{*}{$\begin{array}{l}\text { Bet } \\
\text { we } \\
\text { en } \\
\text { Gro } \\
\text { ups }\end{array}$} & $\begin{array}{l}\text { (Combi } \\
\text { ned) }\end{array}$ & 213.050 & $\begin{array}{l}1 \\
1\end{array}$ & $\begin{array}{r}19.36 \\
8 \\
\end{array}$ & $\begin{array}{r}.77 \\
3 \\
\end{array}$ & $\begin{array}{r}.66 \\
1 \\
\end{array}$ \\
\hline & & $\begin{array}{l}\text { Lineari } \\
\text { ty }\end{array}$ & 41.562 & 1 & $\begin{array}{r}41.56 \\
2 \\
\end{array}$ & $\begin{array}{r}1.6 \\
60 \\
\end{array}$ & $\begin{array}{r}.21 \\
7 \\
\end{array}$ \\
\hline & & $\begin{array}{l}\text { Deviati } \\
\text { on } \\
\text { from } \\
\text { Lineari } \\
\text { ty }\end{array}$ & 171.488 & $\begin{array}{l}1 \\
0\end{array}$ & $\begin{array}{r}17.14 \\
9\end{array}$ & $\begin{array}{r}.68 \\
5\end{array}$ & $\begin{array}{r}.72 \\
4\end{array}$ \\
\hline & \multicolumn{2}{|c|}{ Within Groups } & 375.617 & $\begin{array}{l}1 \\
5\end{array}$ & $\begin{array}{r}25.04 \\
1\end{array}$ & & \\
\hline & \multicolumn{2}{|c|}{ Total } & 588.667 & $\begin{array}{l}2 \\
6\end{array}$ & & & \\
\hline
\end{tabular}

Berdasarkan hasil uji linieritas di atas bahwa nilai sig deviation from linierity sebesar $0,724>0,05$, maka dapat disimpulkan bahwa terdapat pengaruh yang linier antara pembelajaran blanded learning $(\mathrm{X})$ dengan nilai-nilai karakter $(\mathrm{Y})$.

\section{Pengujian Hipotesis}

Pengujian hipotesis peneliti menggunakan analisi data regresi linier sederhana yang bertujuan untuk memprediksi pengaruh antara variabel $\mathrm{X}$ (pemebelajaran blanded learning) dengan variabel $\mathrm{Y}$ (nilai-nilai karakter).

\section{a. Hasil Uji T}

Pengujian hipotesis uji t ( $t$-test) yang digunakan dalam penelitian ini yaitu bertujuan untuk mengetahui apakah pengaruh variabel $X$ terhadap variabel Y signifikan atau tidak. Dengan rumus jika t hitung $>\mathrm{t}$ tabel atau nilai signifikansinya $<0,05$ maka dapat dikatakan terdapat pengaruh variabel $\mathrm{X}$ terhadap variabel Y. Jika sebaliknya $\mathrm{t}$ 
Illiyinna Rahmi dan Rahmi Wiza: Pengaruh Pembelajaran Blended Learning terhadap ...

hitung $<\mathrm{t}$ tabel atau nilai signifikannya $>0,05$ maka tidak terdapat pengaruh variabel X terhadap Y. Output uji T dapat dilihat pada tabel dibawah ini.

Tabel 7. Hasil Uji T

\begin{tabular}{|c|c|c|c|c|c|}
\hline \multicolumn{6}{|c|}{ Coefficients $^{a}$} \\
\hline \multirow[t]{2}{*}{ Model } & \multicolumn{2}{|c|}{$\begin{array}{l}\text { Unstandardized } \\
\text { Coefficients }\end{array}$} & \multirow{2}{*}{$\begin{array}{c}\text { Standardize } \\
\text { d } \\
\text { Coefficients } \\
\text { Beta }\end{array}$} & \multirow[t]{2}{*}{$\mathrm{t}$} & \multirow[t]{2}{*}{ Sig. } \\
\hline & B & Std. Error & & & \\
\hline $\begin{array}{l}\text { (Connstant) } \\
\mathrm{r}\end{array}$ & 66.178 & 6.550 & & $\begin{array}{r}10 . \\
187\end{array}$ & $\begin{array}{r}.00 \\
0 \\
\end{array}$ \\
\hline $\begin{array}{l}\text { pembelajaran } \\
\text { blanded } \\
\text { learning }\end{array}$ & -.307 & .223 & -.266 & $\begin{array}{r}- \\
1.3 \\
78\end{array}$ & $\begin{array}{r}.18 \\
0\end{array}$ \\
\hline
\end{tabular}

Hasil uji $\mathrm{T}$ di atas dengan rumus $\mathrm{N}=27-2$ maka diperoleh $\mathrm{t}$ hitung $-1.378<\mathrm{t}$ tabel nya 1,708 dan nilai signifikansinya sebesar $0,180>0,05$ maka dapat disimpulkan hasil uji $\mathrm{T}$ penelitian ini signifikan Ha ditolak dan Ho diterima. Sehingga dapat disimpulkan bahwa tidak terdapat pengaruh yang signifikan antara pembelajaran blanded learning (X) terhadap nilai-nilai karakter (Y) pada siswa di SD Negeri 26 Teluk Bayur.

\section{b. Koefisien Determinasi}

\begin{tabular}{|l|cccc|}
\hline Model & $\mathrm{R}$ & R Square & $\begin{array}{l}\text { Adjusted } \\
\text { R Square }\end{array}$ & $\begin{array}{c}\text { Std. Error } \\
\text { of the } \\
\text { Estimate }\end{array}$ \\
\hline $\mathbf{1}$ & $.266^{\mathrm{a}}$ &, 071 &, 033 & 4,67805 \\
\hline a. Predictors: (Constant), pembelajaran blanded learning \\
\hline
\end{tabular}

Koefisien determinasi bertujuan untuk mengetahui seberapa besar variabel $X$ (pembelajaran blanded learning) mempengaruhi variabel Y (nilai-nilai karakter) di SD Negeri 26 Teluk Bayur. Berdasarkan tabel output diatas maka dapat disimpulkan bahwa koefisien korelasi $\left(\mathrm{R}^{2}\right)$ nya sebesar 0,071 $(7,1 \%)$. Hal ini menunjukkan bahwa variabel $\mathrm{X}$ (pembelajaran blanded learning) mempengaruhi variabel $\mathrm{Y}$ (nilai-nilai karakter) sebanyak 7,1\%. Sedangkan sisanya yaitu 93\% lagi dipengaruhi oleh variabel lain yang diluar penelitian. 


\section{B. Pembahasan}

Pembelajaran blended learning merupakan gabungan pembelajaran langsung dan pembelajaran daring/online, siswa harus mencari gaya belajar yang aktif sesuai dengan dirinya, pembelajaran ini memperkuat pembelajaran teknologi masa kini. Dalam proses pembelajaran blanded learning ini siswa diminta untuk lebih aktif mencari gaya pembelajaran sendiri sehingga banyaknya siswa yang merasa jenuh, bosan, dan merasa tidak semangat untuk belajar. Proses pembelajaran blanded learning yang diterapkan di SD Negeri 26 Teluk Bayur ini dibagi menjadi 3 hari proses pembelajaran daring dan 3 hari proses belajar tatap muka/ luring disetiap minggunya.

Pembelajaran blanded learning juga berpengaruh terhadap karakter siswa, baik karakter positif maupun negatif, namun banyaknya karakter negatif berasal dari penerapan pembelajaran daring diantaranya siswa kurang semangat dalam belajar, siswa tidak disipilin dalam mengumpulkan tugas, dan kurangnya kejujuran siswa dalam menyelesaikan tugas-tugas yang diberikan guru.

Berdasarkan buku tema siswa kelas $\mathrm{V}$ penilaian sikap yang harus diterapkan diantaranya religius, disiplin, jujur, tanggung jawab, dan sopan santun. Saat pembelajaran daring karakter disiplin siswa masih kurang terealisasi tampak dari hasil jawaban dominan 51\% kadang-kadang mengumpulkan tugas tepat waktu. Begitupun pada saat pembelajaran luring/ tatap muka tidak semua siswa yang dapat menerapkan semua nilai karakternya, terlihat dari jawaban dominan 33\% sangat sering terlambat ke sekolah dan 33\% sangat sering mengumpulkan tugas di luar jadwal pembelajaran.

Berdasarkan hasil kuesioner (angket) yang telah peneliti berikan kepada 27 responden di SD negeri 26 Teluk Bayur pada kelas V, diketahui bahwa hipotesis nihil (Ho) dalam penelitian ini diterima dengan artian dugaan awal ada pengaruh pembelajaran blanded learning terhadap nilainilai karakter siswa di SD Negeri 26 Teluk Bayur ini ditolak.

Ketika Ha ditolak maka pada hipotesis nihil (Ho) pada penelitian ini diterima, artinya tidak ada pengaruh antara pembelajaran blanded learning terhadap nilai-nilai karakter siswa di SD Negeri 26 Teluk Bayur. Berdasarkan hasil uji $\mathrm{T}$ dengan rumus $\mathrm{N}=27-2$ maka diperoleh $\mathrm{t}$ tabelnya 1,708 , artinya t hitung $-1,378<$ dari t tabel 1,708 dan nilai signifikansinya sebesar 0,180 >0,05 maka dapat disimpulkan hasil uji $\mathrm{T}$ penelitian ini signifikan Ha ditolak dan Ho diterima.

Maka didapatkan dari koefisien determinasi yang bertujuan untuk mengetahui seberapa besar pengaruh yang diberikan dari variabel $\mathrm{X}$ terhadap variabel $Y$ yaitu koefisien korelasi $\left(R^{2}\right)$ nya sebesar $0,071(7,1 \%)$. Hal ini menunjukkan bahwa variabel $X$ (pembelajaran blanded learning) mempengaruhi variabel Y (nilai-nilai karakter) sebanyak 7,1\%. Sedangkan sisanya yaitu 93\% lagi dipengaruhi oleh variabel lain yang diluar penelitian

Berdasarkan penjelasan diatas, dapat disimpulkan bahwa tidak ada pengaruh pembelajaran blanded learning terhadap nilai-nilai karakter 
Illiyinna Rahmi dan Rahmi Wiza: Pengaruh Pembelajaran Blended Learning terhadap ...

siswa SD 26 Teluk Bayur, meskipun tidak ada pengaruh antara dua variabel, namun hal tersebut tidak boleh diabaikan dan harus selalu dipertahankan karakter yang di terapkan oleh siswa dalam proses pembelajaran blanded learning.

\section{Simpulan}

Berdasarkan temuan dan pembahasan hasil penelitian, maka dapat disimpulkan:

a. Pada pembelajaran blanded learning (X) tidak terdapat pengaruh terhadap nilai-nilai karakter (Y) siswa SD Negeri 26 Teluk Bayur. Karena dalam proses pembelajaran blanded learning guru dapat mengontrol karakter siswa sehingga tidak begitu berpengaruh pembelajaran ini terhadap nilai-nilai karakter dan semua nilai karakter telah diterapkan di SD Negeri 26 Teluk Bayur tersebut.

b. Hasil pengujian hipotesis secara parsial dengan rumus $\mathrm{N}=27-2$ maka diperoleh $\mathrm{t}$ hitung $-1,378<\mathrm{t}$ tabel 1,708 dan nilai signifikansinya sebesar 0,180 > 0,05 maka dapat disimpulkan hasil uji $\mathrm{T}$ penelitian ini signifikan Ha ditolak dan Ho diterima. Sehingga dapat disimpulkan bahwa tidak terdapat pengaruh yang signifikan antara pembelajaran blanded learning (X) terhadap nilai-nilai karakter (Y) pada siswa di SD Negeri 26 Teluk Bayur.

c. Koefisien determinasi bertujuan untuk mengetahui seberapa besar pengaruh yang diberikan dari variabel $\mathrm{X}$ terhadap variabel $\mathrm{Y}$ yaitu koefisien korelasi $\left(\mathrm{R}^{2}\right)$ nya sebesar 0,071 (7,1\%). Hal ini menunjukkan bahwa variabel $X$ (pembelajaran blanded learning) mempengaruhi variabel Y (nilai-nilai karakter) sebanyak 7,1\%. Sedangkan sisanya yaitu 93\% lagi dipengaruhi oleh variabel lain yang diluar penelitian.

\section{Referensi}

Husamah, H. (2014). Pembelajaran bauran (Blended learning). Research Report.

Hussin, Z., Siraj, S., Darusalam, G., \& Salleh, N. H. M. (2017). Kajian Model Blended Learning dalam Jurnal Terpilih: Satu Analisa Kandungan. JuKu: Jurnal Kurikulum \& Pengajaran Asia Pasifik, 3(1), 1-6.

Menteri Pendidikan dan Kebudayaan Republik Indonesia. (2020). Surat Edaran Nomor 4 Tahun 2020 Tentang Pelaksanaan Kebijakan Pendidikan Dalam Masa Darurat Penyebaran Coronavirus Disease (COVID-19). Republik Indonesia.

Salma, D., Ariani, D., \& Handoko, H. (2013). Mozaik Teknologi Pendidikan: ELearning. Jakarta: PT Fajar Interpratama Mandiri, 2103.

Soekartawi, A. H., \& Librero, F. (2002). Greater learning opportunities through distance education: experiences in Indonesia and the Philippines. Journal of Southeast Asian Education, 3(2), 283-320.

SP, J. I. (2016). Penanaman Nilai-Nilai Karakter Melalui Implementasipendidikan Karakter Di Sekolah Dasar. Prosiding Seminar Nasional Inovasi Pendidikan.

Sudrajat, A. (2011). MENGAPA PENDIDIKAN KARAKTER? | Sudrajat | Jurnal Pendidikan Karakter. Journal Pendidikan Karakter.

Susandi, A. (2017). The Influence Model Blanded Learning of Social Sciences Subjects Respecting Indonesian Ethnic and Cultural Diversity To Increasing Activity And Learning Outcomes of Grade V Students in Elementary School 1 
Purwoharjo Banyuwangi Distric Year 2015/2016. Pancaran Pendidikan, 6(3).

Syarifudin, A. S. (2020). IMPELEMENTASI PEMBELAJARAN DARING UNTUK MENINGKATKAN MUTU PENDIDIKAN SEBAGAI DAMPAK DITERAPKANNYA SOCIAL DISTANCING. Jurnal Pendidikan Bahasa Dan Sastra IndonesiaMetalingua. https://doi.org/10.21107/metalingua.v5i1.7072

Yurianto, A. (2020). Pedoman Pencegahan dan Pengendalian Coronavirus Disease (COVID-19). Germas. 